\title{
FENOMENA POSTING MEME DI INSTAGRAM (Studi Pada PNS Bappeda Provinsi Bengkulu)
}

\author{
Oleh: \\ I N D R I A \\ Dosen Program Studi Ilmu Komunikasi Fakultas Ilmu-Ilmu Sosial \\ Universitas Dehasen Bengkulu
}

\begin{abstract}
Social media nowadays is able to be a new media phenomenon which close to the Indonesian society, especially for the adolescents and adults. With the social media power as a cyber characteristic frequently produce the phenomena which have been booming for the social media users themselves. In this research, researchers are interested to review the meme phenomena in Instagram as social media. The type of this research is qualitative research. The informants of this research is public employees (PNS) Bappeda Bengkulu Province as Instagram users which regularly active to post memes using meme pictures on their Instagram accounts. Females are considered to be more expressive in front of people. The results of this research showed that there were three motives behind the memes posting activities by Instagram users, which are for entertaining, love, and soul expression. Moreover, in order to interpret the activities of memes posting which have done by Instagram users, researcher figured two main points which are Instagram users feel observed by followers and give the informations for the intagram followers. Therefore, it can be concluded that the meme phenomena is one of the phenomena which the social media users delivering the messages in the new forms by combining the verbal languages with nonverbal communication (expression).
\end{abstract}

Keywords: Meme, Social Media, Instagram

\section{PENDAHULUAN}

Hadirnya kecanggihan teknologi komunikasi hingga saat ini sedikit banyak telah mempengaruhi tingkah polah masyarakat global dewasa ini. Seiring pesatnya perkembangan teknologi dan informasi secara kasat mata berdampak pada kehidupan manusia yang mana menghasilkan kedekatan secara personal. Satu orang pemilik akun ternyata tidak hanya mengakses satu media sosial yakni bisa saja satu orang menggunakan 2,3 atau lebih media sosial seperti disaat seseorang memiliki facebook dia juga memiliki akun lain contohnya twitter, whatsapp, bbm, line, instagram, path dan lainnya. Sebagai makhluk sosial sejatinya kita sulit memungkiri di era digital seperti saat ini tidak mengunakan berbagai fasilitas kemudahan yang diberikan oleh teknologi disekeliling kita. Hal inipun disepakati oleh Purbo dalam bukunya Pri-Hatna (2005:7), internet dengan berbagai aplikasi seperti web, V0IP, dan email pada dasarnya merupakan media yang digunakan untuk mengefisiensikan proses 
komunikasi. Sebagai contoh, saat ini di institusi pemerintahan kota Bengkulu pun mewajibkan seluruh Lurah sekota Bengkulu untuk memiliki akun whatsapp demi memudahkan berkomunikasi. Misalnya ada beberapa kegiatankegiatan yang diselenggarakan oleh salah satu kelurahan bisa dilaporkan melalui whatsapp kepada Camat dan dapat diketahui pula oleh Lurah lain.

Karakteristik media sosial yang notabene sangat mudah diakses melalui handphone yang berbasis android ataupun secara sederhana dapat mengakses google maka hal ini dapat dikatakan accessible. Dari yang didesa hingga wilayah perkotaan, mulai anak sd hingga bosbos perusahaan dapat mengakses media sosial. Ini dapat menjadi fenomena sendiri bagi masyarakat dimana bukan hal yng aneh jika menjadi sebuah topic bahasan. Di media sosial pulalah kita mengenal beragamnya fenomena-fenomena dimulai dari fenomena selfie yang dilakukan mulai dari rakyat biasa hingga Obama, golongan jilboobs, berfoto di tempat-tempat wisata dengan \#hashtagmy trip my adventure yang turut melariskan produk dengan tulisan yang sama, baru-baru ini heboh berfoto di Instagram dengan bertukaran baju dengan pasangan dimana pacar cewek menggunakan baju cowoknya begitupun sebaliknya hingga fenomena meme yang menjadi ketertarikan tersendiri bagi penulis untuk ditelusuri lebih jauh.Fenomena ini muncul dan berkembang melalui media-media sosial yang diminati oleh masyarakat khususnya usia remaja hingga dewasa seperti facebook, twitter, path dan
instagram.Didalam situs merdeka.com dituliskan bahwa meme adalahbentuk ekspresi seseorang yang ditumpahkan lewat gambargambar.Menurut Bauckhage (2011), meme biasanya berkembang melalui komentar, imitasi, parody bahkan hasil pemberitaan di media.

Alasan booming-nya meme tidak lepas dari pengaruh pengguna media sosial itu sendiri dalam proses penyebaran informasi terkait topik meme yang popular saat ini. Secara kasat mata dapat dilihat tertarik atau tidaknya seseorang kepada gambar meme yang disebarkan yakni pengguna akan melakukan reposting, upload bahkan mengganti gambar profil akun pribadi miliknya dengan meme yang popular tersebut. Disaat banyak merasa setuju dengan gambar meme tersebut maka tak jarang orang-orang tersebut menjadikan meme tersebut sebagai sesuatu yang popular atau dalam istilah twitter adalah trending topic. Beberapa tahun terakhir seiring berkembangnya fenomena meme, kita tak heran dalam dimana melihat gambar meme Prabowo vs Jokowi lengkap dengan tulisan-tulisan cenderung memojokkan keduanya saat pemilihan Presiden berlangsun, Haji Lulung vs Ahok, meme \#disitu kadang saya merasa sedih, dan masih banyak lagi. Untuk lebih jelasnya kita bisa melihat seperti apa gambargambar meme itu dapat melalui situs memecomicindonesia.net atau bahkan kita bisa turut berpatisipasi dalam membuat gambar meme melalui memecomic.id dan melalui instagram dengan nama akun @ memecomicindonesia.

Awalnya penulis menganggap hal ini sangat biasa dan 
unik karena masyarakat kita membutuhkan hiburan dan sesuatu yang segar ada banyak hal yang bisa ditertawakan untuk menghilangkan stress melalui gambar. Seperti akun instagram milik @ memecomicindonesia yang menuliskan di profil instagram nya yakni gambar-gambar yang diposting semata-mata hanya untuk hiburan. Namun semakin kesini penulis menilai ada sesuatu yang perlu dilihat lebih jauh bukan hanya gambar dan tulisan yang lucu tetapi telah menghadirkan alasan-alasan berbeda bagi pengguna media sosial yang mengakses gambar-gambar dari memecomic tersebut. Ada banyak gambar meme yang popular ditujukan kepada kaum "jomblo" atau sebutan untuk orang yang tidak mempunyai pasangan salah satunya adalah gambar seorang cewek yang tengah membaca pesan di handphone ditambah dengan tulisan "malam minggu ngecheck bbm dari pacar, eh lupa kalo gapunya" dan masih banyak lagi. Apabila hanya postingan ringan seperti itu tidak begitu menyita perhatian penulis. Namun ada banyak gambar meme yang cenderung menggunakan bahasa vulgar sementara yang mengakses situs bahkan media sosial tidak semuanya dewasa sementara konten yang dihadirkan tidak sepatutnya mereka lihat Contoh : lirik lagu kesempurnaan cinta milik Rizky anak comedian Sule diplesetkan seperti ini "Berada di kos-kosan mu mengajarkanku apa artinya kenyamanan, kesempurnaan cinta". Ini akan menimbulkan makna yang diartikan negatif oleh orangorang yang membaca dan melihat. Selain dua contoh diatas masih banyak gambar meme dengan beragam isi pesan yang ada didalamnya.

Gambar meme tak ubahnya komik yang didalamnya terdapat gambar dengan kalimat yang bermakna. Apabila komik kebanyakan bersifat hiburanbagi pembaca namun berbeda dengan meme yang justru dapat menimbulkan pro dan kontra bagi yang menyaksikan. Di satu sisi ada pembaca atau pengikut gambar meme yang menganggap hal tersebut hanya sebagai lelucon namun disisi lain ada yang menganggap pada gambar meme yang dianggap lelucon itu justru menyakitkan bagi orang yang menjadi objek lelucon atau keluarga dari objek lelucon tersebut. Penulis mengambil contoh dimana terdapat hal yang tidak baik untuk dijadikan lelucon adalah "Kopi Mirna" dimana beberapa waktu lalu kasus ini sempat menyita perhatian masyarakat Indonesia. Adapun gambar meme yang ditampilkan di media sosial adalah gambar Jesika dengan tulisan “yuk ngopi sama aku?". Proses persidangan masih berlangsung dimana kita masyarakat belum mengetahui apakah benar Jesika yang menyebabkan kematian Mirna apakah ada orang lain, dan bagaimana perasaan orang tua mirna menyaksikan banyaknya beredar gambar meme tersebut? Terlebih bagaimana pula perasaan Orangtua Jesika melihat banyaknya orang yang menghakimi anak kandungnya. Sejatinya masih banyak objek-objek lain yang dapat dijadikan bahan lelucon namun justru trend di media sosial membawa masyarakat justru tertarik untuk menggabungkan lelucon melalui gambar meme 
dengan hal-hal yang menjadi sorotan public akhir-akhir ini.Tidak hanya itu adapula gambar meme ringan yang berisikan hal-hal yang dapat merepresentasikan pesan yang ingin diungkapkan oleh seseorang sehingga orang tersebut menjadikan display picture, mengupload, bahkan me-repath gambar tersebut diakun media sosial miliknya, contoh sederhana yaitu gambar seorang cowok dengan tulisan "beri aku kekuatan dan ketabahan dalam menghadapi cobaan ini ketika ditanya kapan nikah?”.

Peneliti tertarik mengambil fenomena posting meme di media sosial karena meme dapat dikatakan sebagai media penyampaian pesan dalam bentuk baru. Dimana seiring dengan berkembangnya penggunaan media sosial oleh masyarakat maka turut pula mempopulerkan gambar meme ditengah masyarakat. Hal ini menarik dimana menggabungkan antara komunikasi nonverbal (gambar dan ekspresi) dengan komunikasi verbal (bahasa) sehingga menghasilkan sebuah pesan. Dari berbagai jenis gambar meme yang popular, peneliti tertarik untuk membahas bentuk posting meme yang dilakukan oleh pengguna media sosialtwitter dan instagram yang memposting gambar yang sesuai dengan kondisi yang tengah mereka alami atau sesuai dengan perasaan mereka. Dan dalam hal ini fokus penelitian yaitu pada Pegawai Negeri Sipil (PNS) Bappeda Provinsi di Bengkulu. Berdasarkan pengalaman dan hal-hal disekitar diketahui bahwawanita dianggap lebih mudah menunjukkan perasaannya melalui sosial media dibandingkan dengan perilaku pria yang lebih menunjukkan gengsi saat mengupload ataupun mem-posting sesuatu. Booming-nya fenomena meme di media sosial khusunya instagram saat ini merupakan hal yang mendasari peneliti untuk mengetahui motif dan makna user khususnya instagram dalam melakukan posting meme tentang dirinya tersebut. Ada beberapa hal yang mnggelitik peneliti untuk mengetahui alasan dari pengguna melakukan posting meme tersebut apakah salah satunya yakni ingin menunjukkan citra diri mereka dengan eksistensi nya dalam memposting gambar meme tersebut sehingga banyak dilihat oleh followers bahkan khalayak luas, hanya sekedar hiburan atau ada alasan-alasan lain.

\section{METODE PENELITIAN}

Adapun metode yang digunakan dalam penelitian ini adalah kualitatif. Metode merupakan suatu prosedur atau cara untuk mengetahui se- suatu yang mempunyai langkah-langkah sistematis sedangkan metodologi ialah suatu pengkajian dalam mempelajari peraturan-peraturan suatu metode. Dalam penelitian ini, peneliti menggunakan penelitian secara kualitatif, dimana menurut Jane Richie (Moleong, 2004:6) penelitan kualitatif merupakan upaya untuk menyajikan dunia sosial dan perspektifnya dalam segi konsep, perilaku, persepsi dan persoalan manusia yang diteliti. Sejalan dengan pendapat Bogdan dan Taylor (Moloeng, 2002:3) yang menyatakan bahwa metode kualitatif sebagai prosedur penelitian yang 
menghasilkan data deskriptif berupa kata-kata tertulis atau lisan dari orang-orang dan perilaku yang dapat diamati.Penelitian kualitatif adalah penelitian yang dilakukan pada kondisi objek yang alami, peneliti sebagai instrumen kunci, teknik pengumpulan data dilakukan secara gabungan, data yang dihasilkan bersifat deskriptif, analisis data dilakukan secara induktif, dan penelitian ini lebih menekankan makna daripada generalisasi (Sedarmayanti dan Hidayat, 2011: 33).

Melihat dari permasalahan diatas, peneliti mencoba menganalisa Fenomena Posting meme di Media Sosial dengan menggunakan teori yang dinilai tepat dalam pembahasan ini adalah Teori uses \& gratification dimanateori komunikasi ditentukan oleh si individu tersebut dalam memilih pesan dari media dan didasari oleh motif yang disesuaikan kebutuhan masing-masing individu. Media sosial tergolong media baru atau new media yang tentunya memudahkan antar individu untuk saling berkomunikasi. Sudah tidak asing lagi dengan istilah new media dapat mendekatkan yang jauh sekaligus menjauhkan yang dekat. Tak heran pula kita temukan disekitar kita begitu banyak orang yang terlalu aktif disosial media justru pasif didunia nyata atau bahkangara-gara media sosial seorang suami tidak memperdulikan keberadaan istri disebelahnya begitupun sebaliknya. Teori uses and gratification dan Teori Memetika. Mengapa ini dianggap tepat? Karena penggunaan sosial media oleh seseorang adalah berdasarkan fungsi dan kepuasan seseorang dalam memilih dan menggunakan media sosial demi memenuhi kebutuhannya. Dalam hal ini pengguna media memainkan peran aktif dalam memilih media tersebut. Pengguna media berusaha mencari sumber media yang paling baik di dalam usaha memenuhi kebutuhannya. Sementara Teori Memetika yang dirumuskan oleh Richard Dawkins, evolusi kebudayaan juga dianggap tepat untuk menjadi landasan karena ini berkaitan dengan evolusi biologis. Dimana ada suatu kebebasan dalam diri manusia untuk menentukan perubahan suatu kebudayaan, itupun tidak terlepas dari suatu proses alami dari gambar meme berkembang dari satu otak ke otak yang lain.

\section{HASIL PENELITIAN DAN PEMBAHASAN}

Berdasarkan wawancara yang dilakukan secara langsung kepada informan, peneliti mendapatkan data pendukung tentang fenomena meme perempuan yang sudah bekerja tepatnya di Bappeda Provinsi Bengkulu sebagai penguna media sosial instagram terkait dengan pembahasan penelitian, yakni mengenai motif dan makna pengguna instagram melakukan aktivitas posting dan upload meme dengan tema tertentu di instagram. Melalui penelitian ini, akan diketahui motif pengguna instagram melakukan aktivitas posting meme tentang dirinya.

\section{Motif Pengguna Melakukan Posting Meme}

Setelah melakukan penelitian, ditemukan beberapa motif pengguna yang dalam hal ini dilihat dari 
Pegawai Negeri Sipil (PNS) Bappeda Provinsi Bengkulu yang menggunakan instgram, diantaranya

1. Motif Menghibur; Adanya keinginan untuk menghibur followers dengan posting meme membuat informan semakin tertarik untuk menampilkan meme dengan ide-ide yang menghibur dan menggunakan topik-topik yang menarik untuk dijadikan meme. Dari aktivitas menghibur ini, informan merasa mendapatkan tanggapan yang baik dari followers-nya. Hal ini ditunjukkan dengan reaksi dari temanteman informan yang menyukai hasil meme yang dibuat oleh informan.

2. Motif Cinta; Motif ini muncul dan dirasakan oleh informan karena adanya interaksi yang terjadi antara informan dengan followers-nya. Pemberian likers dan komentar yang positif membuat informan merasa disukai oleh followers-nya. Selain itu, rasa menyukai dan disukai juga timbul dari adanya respons followers yang meminta infoman untuk membuatkan meme yang sesuai dengan kemauan followers. Tentunya hal ini menunjukkan bahwa antara informan dengan followers-nya terjalin hubungan persahabatan dan saling menerima serta mempercayai satu sama lain. Informan memiliki keinginan untuk membuat meme terus-menerus yang tentunya lebih lucu dan menarik.

3. Motif Ekspresi Jiwa; Motif informan melakukan posting meme untuk di upload di Instagram karena ingin mengekspresikan meme yang posting sebagai bentuk perasaan yang sedang mereka alami. Hal tersebut terkesan menyenangkan dan dengan menunjukkan ekspresinya tersebut mereka menganggap sosial media tidak membosankan. Dalam hal ini, peneliti melihat bahwa informan melakukan hal yang baru dengan menunjukkan hal-hal yang dirasakannya melalui posting meme di akun sosial media mereka.

\section{PENUTUP}

Setelah melakukan wawancara dan analisis menggunakan teori yang relevan, dapat disimpulkan bahwa motif utama pengguna instagram dalam mem-posting dan melakukan upload meme adalah motif hiburan, menujukkan cinta dan ekspresi jiwa . Penyebaran meme melalui instagram diterjemahkan oleh Pegawai Negeri Sipil (PNS) Bappeda Provinsi Bengkulu adalah adanya keinginan mereka untuk menghibur followers dengan hasil-hasil posting meme yang dilakukan, mendapat respon seperti likers dan komentar yang positif membuat informan merasa disukai oleh followers, dan Informan ingin mengekspresikan meme yang mereka post merupakan ekspresi jiwa mereka tanpa menunjukkan secara langsung followers dapat menterjemahkan dari gambar meme yang di uploadArtinya, informan merasa bahwa komentar yang diberikan oleh followers dapat memengaruhi perasaan informan. Dari hasil wawancara dan analisis yang dilakukan, peneliti menemukan kesan bagaimana pengguna instagram memaknai aktivitas 
posting meme yang dilakukannya. Yang pertama, informan merasa diperhatikan followers, dengan pemberian like dan commentfollowers terhadap posting meme membuat informan merasa diperhatikan. Kedua, informan merasa telah memberikan informasi secara tidak langsung pada followers melalui hashtag, terkait dengan meme yang akan dicari. Terakhir, informan merasa mendapatkan pengalaman baru, teman baru dengan semakin bertambahnya followers, menghilangkan rasa bosan dan stres khususnya dalam pekerjaan, serta dapat saling menginspirasi.

\section{DAFTAR PUSTAKA}

Berger, Charles R; Rollof, Michael E ; Roskos, David E. 2014. Handbook Ilmu Komunikasi. Bandung :Nusa Media.

Moloeng, Lexy J. 2002. Metodologi Penelitian Kualitatif. Bandung: PT. Remaja Rosdakarya.

Mulyana, Deddy. 2007. Ilmu Komunikasi: Suatu Pengantar. Bandung: Rosda.

Prihatna, Henky. 2005. Kiat Praktis Menjadi Webmaster Profesional. Jakarta: PT Elex Media Komputindo.

Instagram. 2016. About Us. Diakses pada tanggal 13 Januari 2016, pukul 18.21 dari www.instagram.com: http://instagram.com 